\title{
Formation Conditions and Exploration Directions of Large Cretaceous Sub-salt Oil and Gas Reservoirs in Santos Basin
}

\author{
KunQiang Jin ${ }^{1}$, Yunfeng Zhang ${ }^{2 *}$ \\ ${ }^{1}$ School of Earth Sciences, Northeast Petroleum University, China \\ ${ }^{2}$ School of Earth Sciences, Northeast Petroleum University, China
}

\begin{abstract}
The rich oil and gas resources and good reservoir-forming conditions in the Santos Basin in Brazil make it a majorstrategic succession area for oil and gas exploration in the Santos Basin. The sub-salt bio-reservoir-cap configuration in the SantosBasin can be divided into two types: bio-reservoir-cap superposition and bio-reservoir superposition; the preservation conditions canbe divided into cap-slip-off extension deformation type, and the cap-layer is strongly extruded Deformation type, 3 types of capping stable extrusion deformation type; reservoir formation zone can be divided into 2 types: subsalt raw salt storage and subsalt raw salt storage. The high area outside the Santos Basin in the sub-salt source-salt storage zone is a favorable exploration direction for finding large oil and gas areas under the salt in the Santos Basin.
\end{abstract}

\section{1 introduction}

The Santos Basin is one of the largest coastal passive marginal basins in Brazil. Located on the southeastern coast of Brazil, it is in the NE-SW direction, with a length of about $800 \mathrm{~km}$, a width of about $600 \mathrm{~km}$, and an area of $32.6867 \times 104 \mathrm{~km}^{2[1 \sim 2]}$. It can be divided into four structural units: the central low convex zone, the outer high zone, the outer ultra-deep water zone, and the middle offshore low concave zone (Figure 1) ${ }^{[3 \sim 5]}$. From the bottom to the top of the Santos Basin, there are Picarras Formation, Itapema Formation, Barra-Velha Formation and Ariri Formation of Camboriu Group from bottom to top (Figure 2).

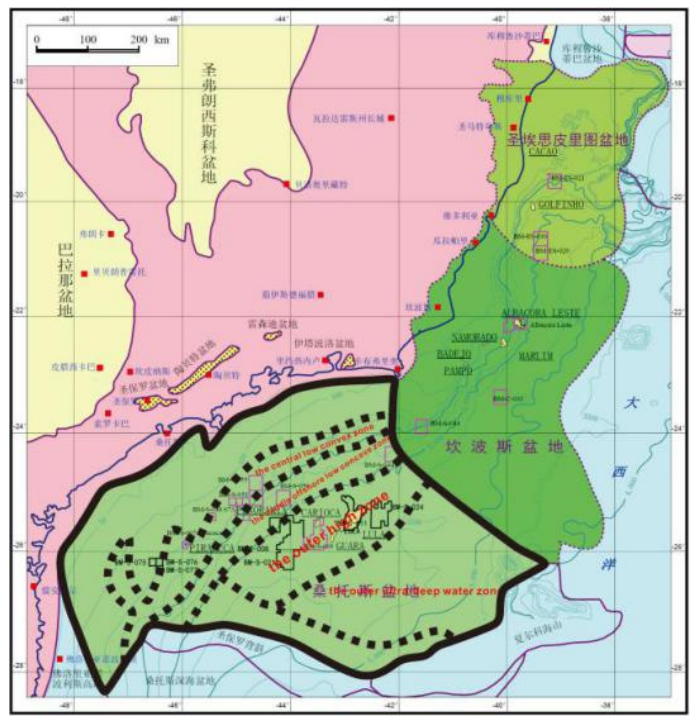

Corresponding author: 1033699387@qq.com
Fig.1 Structural unit of Santos Basin

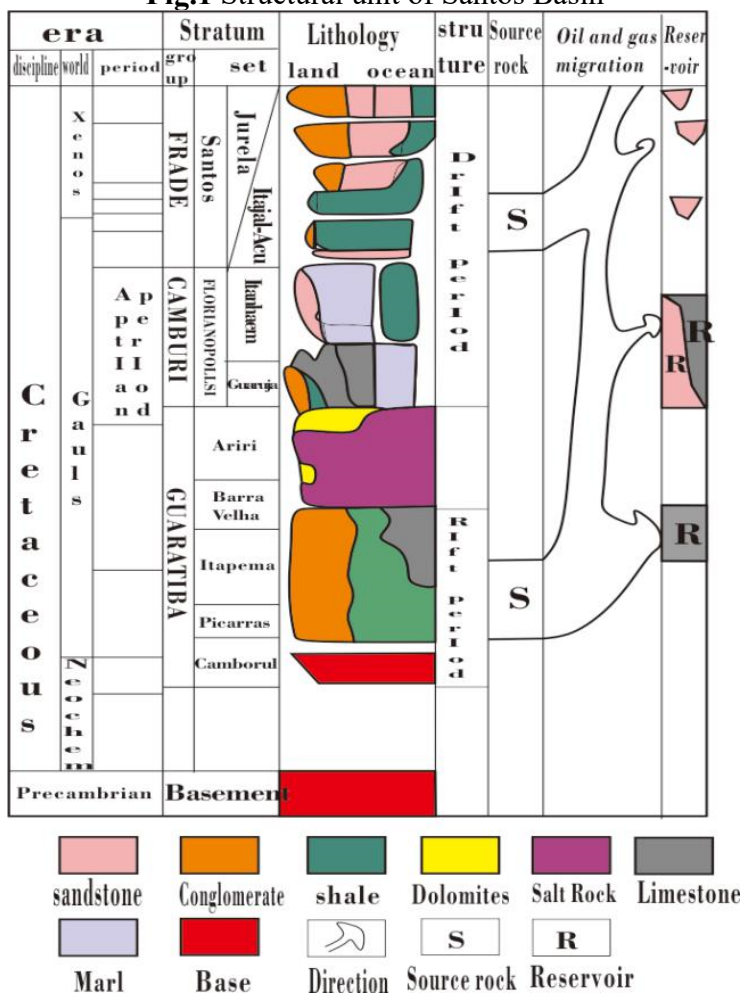

Fig.2 Column chart of subsalt stratum in Santos Basin

\section{Conditions for raw storage and capping}


In the Lower Cretaceous Barremian-Lower Apterian stage, the salt lake facies shale source rock of the Guaratiba Group, the reservoir of the Guaratiba Group, and the cap layer of the Ariri Formation form a good vertical generation-reservoir-cap combination in the Santos Basin.

\subsection{Source rocks}

The Picarras Formation and Itapema Formation of the Lower Cretaceous Guaratiba Group in the Santos Basin, Brazil, developed a set of source rocks, which are sub-salt rift stage Cretaceous Baremian-Lower Aptian lacustrine black calcareous shale, which is the Santos Basin. On the whole, the main source rocks of the sub-salt lake source rocks are characterized by high organic matter abundance, good types, and high hydrocarbon generation potential. Among them, the TOC content is $2 \%-4 \%$, and the maximum hydrogen index can reach $500 \mathrm{gHC} / \mathrm{TOC}$, Showing lipid-rich algae and bacterial material accompanying the development of stromatolites, kerogen is of type I/II or II/I, and the maturity of source rocks varies greatly. It is a set of very high-quality source rocks that The hydrocarbon potential is huge.

\subsection{Reservoir}

The main reservoir of the subsalt lacustrine carbonate rocks in the Santos Basin is the Guaratiba Group: (1) Itapema group shell limestone is a high-energy beach facies sedimentary environment of the shore and shallow lake. The pore types are mainly mold pores and intergranular dissolved pores, and reservoir porosity $6 \% \sim 30 \%$, average value 16\%; (2)Barra Velha Formation spherulite limestone is a high-salinity shallow lake low-energy sedimentary environment, mainly intergranular pores, reservoir porosity $6 \%-25 \%$, average $14 \%$; (3) BarraVelha group algae laminated limestone is a high-salinity high-environment sedimentary environment of the shore and shallow lakes, mainly with biological lattice pores and intergranular pores. The reservoir porosity is $6 \%$ to $20 \%$, with an average value of $12 \%$. Large area continuous distribution.

\subsection{Cover}

Apte evaporite constitutes the regional caprock of the subsalt sequence in the Santos Basin, and shale and marl constitute the local caprock in the group. The cap rock in the basin area is mainly the Ariri Formation salt rock layer, covering the underlying source rocks of the Picaras Formation and Itapema Formation of the Guaratiba Group. According to drilling analysis, the thickness of the gypsum salt rock is $1000-2000 \mathrm{~m}$. The high-quality cap rock composed of a large area of gypsum salt rock is The accumulation of oil and gas provides good capping conditions.

\subsection{Configuration of Bio-reservoir Cover}

Although there are large areas of source rocks, reservoirs and gypsum-salt cap rocks under the Cretaceous in the Santos Basin, the spatial combination and configuration of their source-reservoir-cap in different regions are very different. The characteristics of reservoir formation have an important influence. The deformation of salt rocks in the Santos Basin is complex, forming a large number of different types of deformation structures. Based on surface outcrop, drilling and seismic data, combined with the sedimentary evolution model, the development-reservoir-cap development characteristics of the Cretaceous sub-salt exploration area and the Its spatial configuration is divided into two types: raw-reservoir-cover overlay and raw-reservoir overlay (Figure 3).

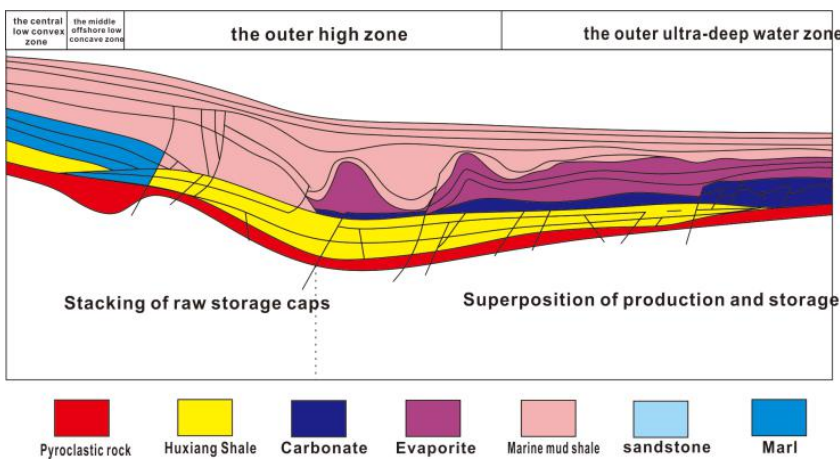

Fig. 3 configuration

\subsubsection{Stacking of raw storage caps}

It is mainly developed in the northeast of the outer high zone and the low depression zone in the offshore. The Huara shale source rocks of the Guaratiba Formation in the rift period are widely developed in these areas, and the Early Cretaceous Apti stage evaporite caprocks are widely distributed in the middle. It contains the high-quality Huxiang Carbonate reservoirs developed on the paleo-uplift structure of the Conquinas and Sag formations of the Lower Aptian stage, including granular limestone, stucco granular rock and granular stuccolite. Long-term formation of a good source-storage-cap combination is very favorable for its accumulation and preservation conditions.

\subsubsection{Superposition of production and storage}

The source-reservoir superimposed type is mainly developed in the northern section of the central low convex belt in the western part of the basin and the northern section of the offshore low depression belt. The source rocks of the Early Cretaceous Guaratiba Formation and the Conquinas and sag Formations developed in Hunan paleo-uplift structure. The high-quality rock reservoir is developed on a large scale, but it lacks large-scale high-quality cap rock. The Early Cretaceous was mainly shale and marl, lacking the capping conditions to form an atmospheric reservoir. 


\section{Storage conditions}

The preservation conditions of the sub-salt exploration area of the Cretaceous in the Santos Basin are evaluated from the degree of cap layer development, faults and tectonic movements, and can be divided into capping slippage deformation type, capping layer strong extrusion deformation type, capping layer stable extrusion deformation type (Figure 4).

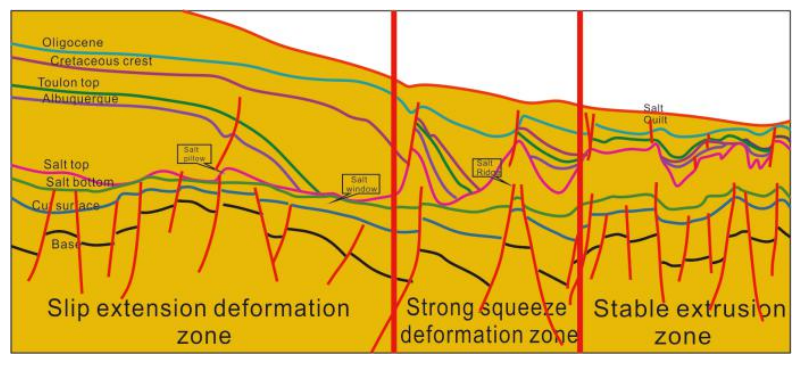

Fig. 4 Salt rock structure style in Santos Basin

\subsection{Extension deformation type of cap slippage}

The cover slippage extension deformation type corresponds to the west slope of the offshore low-sag zone, the western part of the central low-slope zone and the coastal low-sag zone. The formation-reservoir overlaps. The salt rock structure style is dominated by salt windows with a small amount of salt pillows. The overall thickness of the salt rock in the detachment extension deformation zone is small, and the difference is large. The salt rock appears locally. The area is about a few meters to several tens of meters. The distribution of the salt rock is discontinuous, forming a thin salt-free salt oil and gas migration passage area.

\subsection{The cover layer is strongly extruded and deformed}

The strong squeezing deformation type of caprock is mainly distributed in the middle and eastern parts of the offshore low depression zone and the northeastern part of the central low convex zone. There is a superposition of reservoir-reservoir-cover, and the salt rock structure style is mainly salt tower or salt ridge, with a small amount of salt window development. The strong compression deformation zone is located on the west side of the basin. The overall thickness of the salt rock is large, and the difference is large, ranging from a few hundred meters to several thousand meters. The distribution of salt rock is continuous, which constitutes a closed zone of salt rock capping from thin to thick salt.

\subsection{Stable extrusion deformation of cover layer}

The stable squeezing deformation zone is mainly located on the east side of the offshore low-sag zone in the east of the basin and the outer high zone, and the thickness of the superposed salt rock is large, and the salt-salt structural style is dominated by salt. Above about $2000 \mathrm{~m}$, and the distribution is even and continuous, and the multi-flow toughness component constitutes a thick salt rock cap seal zone.

\section{Types of Tibet}

According to such factors as the source-reservoir-cap combination and its spatial configuration, structural stability and preservation conditions, accumulation characteristics and evolution, the sub-salt exploration zone of the Cretaceous in the Santos Basin can be divided into sub-salt accumulation zones and salt There are two types of zones in Tibet(Fig. 5 ).

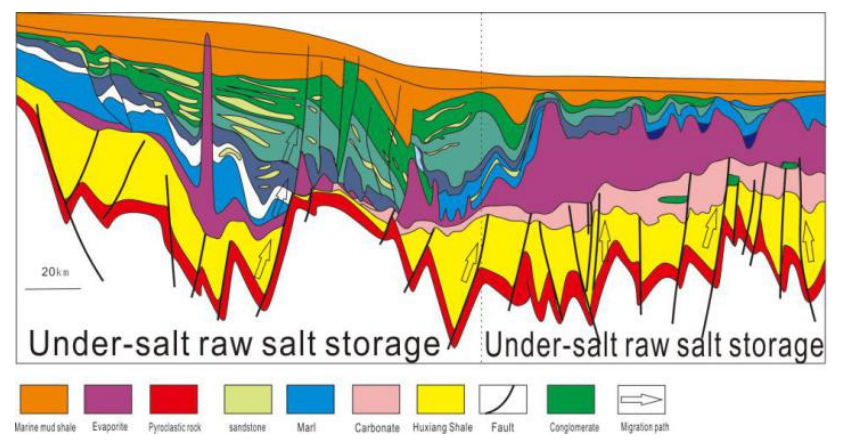

Fig. 5 reservoir forming model

\subsection{Under-salt raw salt storage and accumulation zone}

The upper-salt accumulation model is mainly developed in the salt rock transition zone in the west of the basin, including the low-sag zone near the coast and the low-slope zone offshore. And in the west of the offshore low-sag zone, there are two types of reservoir-forming combinations: "under-salt raw salt storage" and "salt-up raw salt storage".

\subsection{Under-salt raw-salt accumulation zone}

The sub-salt accumulation model is mainly developed in the thick layer of salt rock in the east of the basin, which is mainly distributed in the outer high zone and the east of the offshore low depression zone. The lacustrine shale in the basin is a source rock, the lacustrine bioclastic limestone developed on the paleo-uplift is the reservoir, and the evaporite is the regional cap rock.

In summary, the breakthrough direction of the sub-salt exploration field of the Cretaceous in the Santos Basin should be a continuous stable area of the matching area of the source-reservoir-cap combination, a closed area where the cap layer is not cut and is widely developed. Based on these key elements, the most favorable accumulation area and exploration area in the sub-salt exploration field of the Cretaceous in the Santos Basin can be comprehensively evaluated. The breakthrough target should first be the high zone outside the Santos Basin. 


\section{Conclusion}

(1) The Lower Early Cretaceous Picarras and Itapema Formation source rocks in the Santos Basin are distributed over a large area, and the resources are very rich. The development of the Early Cretaceous Conquinas and Sag Formations can form large-scale high-quality carbonate reservoirs, and the Upper Cretaceous Ariri The large-scale gypsum-salt rock developed in the group is a good cap rock. The longitudinally perfect source-reservoir-cap combination makes the early Cretaceous under the salt of the Santos Basin have the basic conditions for the formation of large oil and gas regions.

(2) Under the salt of the Early Cretaceous in Santos Basin, the source-reservoir-cap combination can be divided into two types: source-reservoir-cap superposition and source-reservoir superposition according to the spatial configuration relationship; the preservation conditions are divided into caprock slip extension deformation type. There are 3 types of strong extrusion deformation of the cover layer and stable extrusion deformation type of the cover layer. The Santos Basin can be divided into two types: subsalt salt storage, and subsalt salt storage.

(3) The high area outside the Santos Basin under the early Cretaceous in the Santos Basin is the most favorable target for breakthroughs in exploration of large oil and gas reservoirs.

\section{references}

1. Yang Haijun, Chen Yongquan, Tian Jun, Du Jinhu, Zhu Yongfeng, Li Honghui, Pan Wenqing, Yang Pengfei, Li Yong, An Haiting. Major discovery and significance of ultra-deep oil and gas exploration in Well Luan 1 in Tarim Basin[J]. Petroleum Exploration in China, 2020 , 25(02): 62-72.

2. Liu Jie. Shell Company starts new subsalt mining in Brazil [J]. Natural Gas Exploration and Development, 2019, 42(04): 18.

3. Liang Jianshe, Huang Xingwen, Cai Wenjie, Wang Ying, Chen Liang, Zhang Yina. Source-sink system and exploration prospect of Wilcox Formation in Perdido structural belt of Burgos Basin, Mexico [J]. Journal of Petroleum, 2019, 40(12): 1439-1450 .

4. Li Tiezhu, Liu Yunbei, Fu Haibo, Xia Fuzhi, Zhao Qinglong, Li Yonggui. Recognition and geological significance of threaded borehole logging in the eastern margin of Binlihai Basin[J]. Foreign Logging Technology, 2019, 40(06): 53-55+70+2.

5. Hissey,Clifford,Debacker. Exploring the sub-salt play in the frontier Amadeus Basin - Insights from regional 2D seismic and potential field data[J]. Taylor \&amp; Francis,2016,2016(1). 